\title{
Impact of Outsourcing on Productivity in Bakery Industry, Abakaliki Metropolis
}

\section{Oluchi EB and Nome $U^{*}$}

Department of Business Management, Marketing and Entrepreneurial Studies, Ebonyi State University, Abakaliki, Nigeria

\begin{abstract}
Management of bakery industry is under pressure of stakeholders to increase equity value. Consumers of bread in Abakaliki Metropolis regret the soaring unit price of the product which managers attribute to increasing cost of outsourcing which result from inflationary economic system. The major objective of this study is to determine the general impact of labour outsourcing on productivity of bakery industries in the area. Three hypotheses were formulated to measure the relationship between outsourcing and operational labour cost, reject bread manufacture and operational time of production. This study was based on Transaction Cost Economics theory propounded by Oliver Williamson (1975). The theory stresses the need for decisions to be made such that it generates economically efficient outcomes. Research instrument adopted was questionnaire. Spearman's correlation was used in data analysis. Results indicate that outsourcing increases the level of efficient production by reducing the operational labour cost and labour time while minimizing the quantity of bread rejects. It is therefore recommended that management of bread industry in the city should intensify outsourcing as a means of reducing unit price of bread and promote Transaction Cost Economics decision for greater productivity.
\end{abstract}

Keywords: Outsourcing; Bakery industry; Abakaliki metropolis

\section{Introduction}

Organisations are established to achieve some predetermined goals in the face of competitions. Today, there is growing pressure on management to satisfy the increasing divergent needs of various stakeholders. There is need to manage scarce resources efficiently. These situations provide management with compelling need to strategies to overcome challenges arising from competition, globalisation and sometimes unfavourable operating climate. Nigerian capitalist environment is dynamic and competitive. Therefore, the only truly general principle manufacturers must adopt is corporate rationality which insists that management must choose alternative which maximises economic efficiency and profitability which results in maximum production of shareholder value $[1,2]$. The corporate rationality criterion states that 'to maximise economic efficiency and corporate profitability, any activity not necessary for production should not be undertaken; any process whose costs are greater than those for similar results from outside suppliers must be outsourced. This corporate rationality function explains the logical basis which makes use of outsourcing imperative. Outsourcing was first used in 1982 [3], to identify the decision by which one or more processes or activities necessary to obtain a product or a component, even an organizational function-originally undertaken in house by a certain organizationare regularly entrusted by a firm -the outsource-to an outside organization, the outsourcer (supplier or provider), who carries out the activity and sells the results to the former. Despite the heterogeneity of definitions, outsourcing has to do with reliance of firms on external sources. Also, the controversial definition of productivity expresses a quantitative relationship between output and input [4,5]. Productivity therefore implies how well the resources are utilized for goods and services generated. The use of productivity as a strategic objective in business is illustrated through the growing importance of low-cost maintenance. Taylor [6] looked at productivity as output divided by inputs. Regardless of the type of production, economic or political system, this definition of productivity remains valid as long as the basic concept is the relationship between the quantity and quality of goods and services produced and the quality and quantity of resources used to produce them [7]. Aggregate measures of productivity in production economics and industrial analysis will add to the sum of our knowledge by serving as barometers of economic progress; as a guide to adjusting resources; providing a framework for formulating and evaluating policy and indicating problem areas that need further research [8]. This gives credence to enhanced productivity as pivot upon which a nation can engender accelerated economic development and growth [9]. A comprehensive measure of productivity is of great importance to both policy-makers and businessmen [10]. Business practice often focus on productivity as one strategic objective indicating that it is an integral part of business strategy. It ensures elimination of wastes such as waiting time, rejects, reworks and work in progress, which invariably indicates a level of efficiency of operations. The term productivity gained popularity in the organization during the world war 11 when it became necessary to increase the volume of war-fighting machines produced, examples, aircrafts, tanks and ships under limited resources. Production was then widely used as the feedback to determine how well and effective the limited resources had been utilized to produce the outputs. Outsourcing and productivity therefore provide strategic alliance for efficient operations of management decisions.

This paper presents an empirical analysis conducted on sample of bakery industries at Abakaliki metropolis, taking into consideration aspects necessary for outsourcing such as business performance, cost reduction and organizational efficiency. Measurement of the impact of outsourcing on productivity is timely due to the simultaneous pressure of three important stakeholders: Shareholders urge management to take all necessary measures to increase equity value; Lenders require

*Corresponding author: Ujebe Nome, Department of Business Management Marketing and Entrepreneurial Studies, Ebonyi State University, Abakaliki, Nigeria Tel: 07015795274; E-mail: Ujebe@hotmail.com

Received Noveber 21, 2017; Accepted December 12, 2017; Published December 22, 2017

Citation: Oluchi EB, Nome U (2017) Impact of Outsourcing on Productivity in Bakery Industry, Abakaliki Metropolis. J Bus Fin Aff 6: 308. doi: 10.4172/21670234.1000308

Copyright: $\odot 2017$ Oluchi EB, et al. This is an open-access article distributed under the terms of the Creative Commons Attribution License, which permits unrestricted use, distribution, and reproduction in any medium, provided the original author and source are credited. 
efficient and profitable management to ensure their money is repaid; financial markets and investors always demand results above previous years'. The adoption of outsourcing strategy could release pressure on management to remain competitive by achieving more with less.

\section{Statement of the problem}

There is increasing demand on management by various stakeholders to ensure increasing equity value and cost reduction. Global recession currently affecting Nigeria has led to geometric increase in cost of doing business. Higher cost of business invariably leads to shrinking profit. Competition and technical innovation have made production and service delivery complex. Deepen states that outsourcing strategy has been credited with helping to cut cost, reduced capital expenditure, greater flexibility, access to talent and skills, access to the latest technology, improve capacity, improve quality, increase profitability and productivity, improve financial performance, lower innovation costs and risks, and improve organisational performance. However, some problems arise from outsourcing like lose of core knowledge, increased cost, low morale, risk of exposing confidential information and hidden cost. Earl asserts that innovation is reduced in the organisation because outsourcing does not favour it. Incidentally, the retail price of bread has risen highly in the recent times. Notwithstanding the numerous amounts of works on the topic, literature still lacks empirical researchers on the real impact of outsourcing on firm productivity.

\section{Objectives of the study}

This research work is aimed at determining the general impact of labour outsourcing on productivity of bakery industries in Abakaliki Metropolis. Specifically, the objectives of the study are:

1. To ascertain the relationship between outsourcing and operational labour costs in the bakery industries selected.

2. To determine the relationship between outsourcing and rejects bread manufacture in the industries selected.

3. To verify the relationship between outsourcing and operational time it takes to produce bread in the selected industries.

\section{Statement of hypotheses}

- $\mathrm{H}_{01}$ : There is no significant positive relationship between outsourcing and operational labour costs in the bakery industries in Abakaliki metropolis.

- $\mathrm{H}_{02}$ : There is no significant positive relationship between outsourcing and rejects bread manufacture in the industries selected.

- $\mathrm{H}_{03}$ : There is no significant positive relationship between outsourcing and operational time it takes to produce bread in the selected industries.

\section{Conceptual Review}

Outsourcing equally known as facilities management can be defined as "the strategic use of outside resources to perform activities traditionally handled by internal staff and resources. Outsourcing is a strategy by which an organization contracts out major functions to specialized and efficient service providers, who become valued business partners. Companies have always hired contractors for particular types of works, or to level off peaks and troughs in their workload, and have formed long term relationships with firms whose capabilities compliment or supplement their own. However, the difference between simply supplementing resources by "Subcontracting" and actual outsourcing is that the latter involves substantial restructuring of particular business activities including, often, the transfer of staff from a host company to a specialist, usually smaller, company with the required core competencies (http://scm.ncsu.edu/scmarticles/a_brief_ history_of_outsourcing).

In the same vein, Okogwu [11] quoting Bryson [12] opines that outsourcing is a viable consideration where the services can be provided more efficiently by an experienced third party. The outsourcing of information and library to focus upon its core businesses or services and re-engineering its business processes.

Okogwu [11] in Bryson [12] further asserts that all the outsourcing process works well in that it stands to achieve the following:

- Save money since the vendor has economics of scale.

- Be more effective since vendors have economies of scale and more specialized experience.

- Lessening of overheads associated with minor services.

Furthermore, Babatunde [13] declares that outsourcing is a management strategy by which an organization delegates major or noncore business functions to specialized and efficient service providers. Economic of globalization and liberalization facilitates the process of searching for opportunities on the one global market to outsource some of organization's activities instead of performing them internally.

Other authors equally wrote on outsourcing and facilities management including Dubem and Okwuashi [14] who acknowledged facilities management (FM) as a discipline that optimizes the delivering of facilities and its related services through use of high profile strategy less through use of high profile strategies that provide cost effective, high quality and concept of managing facilities and its related services.

Outsourcing is the process of establishing and managing a contractual relationship with an external supplier for the provision of capacity that has previously been provide in-house $[15,16]$.

\section{Outsourcing process}

Zoran and Jorgen [15] quoting Momme [16] equally opine that outsourcing is the process of establishing and managing a contractual relationship with an external supplier for the provision of capacity that has previously provided in-house. In spite of an impressive research intensity of the outsourcing process, there are only few frameworks depicting the actual stages and layout of the overall process of outsourcing.

\section{Empirical Review}

Ugochukwu and Nwaoma [17] have carried out a study on outsourcing policy in the Nigeria Public Universities.

Issues and challenges: The paper tries to examine the outsourcing policy in Nigerian Universities and the issues and challenges associated with outsourcing policy. It says that the practice of outsourcing was fast becoming part of the operational strategies of public Universities in Nigeria. According to the paper, the practice derives from various policy reforms of the public institution initiated by the Federal Government of Nigeria. The implementation of outsourcing policy in the public Universities has thrown up a number of challenges and issues that management of these institutions are grappling with. Thus, such challenges and issues border on staff disengagement, inability of the independent contractors to pay minimum wage. 
Contracting out core academic functions, such as teaching and research, the integration of the external service providers into the University culture and the failure to institutionalize effective and efficient regulatory mechanism. The paper was a qualitative study carried out in selected public universities in Nigeria. Both primary and secondary data were collected from these public universities in order to understand the unique experiences of each of these institutions in relation to the managements outsourcing decisions. The primary data were collected through telephone interview which involved primary officers of these institutions.

Furthermore, Okogwu [11] in her study titled "Outsourcing of Library services in Nigeria University Libraries: Pros and Cons. Stated that the economic recession witnessed globally in the late year 2000 affected almost every sector of the economy. The library was not left out. The study reviewed some of the library services that are been outsourced in order to save cost and improve operational efficiency. The paper further investigated the reasons that made libraries outsource their services thus allows the library to focus upon its core businesses or services. It also $\mathrm{x}$-rays the short falls associated with outsourcing of library services. On the other hand, Babatunde [13] carried out a research on outsourcing as a strategic tool for organizational performance: An exploratory study of Nigerian Foods, Beverage and Tobacco Industry. The paper examines outsourcing as a strategic tool for organizational performance using data generated from (five) 5 firms in the bread industry.

Within the period 2000-2010, statistical methods were developed, and the result showed that the more an organization outsourced, the high its organization growth and the organizational productivity and average production cost. The paper also revealed that outsourcing is beneficial to organizational performance and enhances firm's financial economics and competitive advantage in the market place. Therefore, an organization should develop a comprehensive framework to clarify strategic outsourcing objectives, expectations, and requirements towards their outsourcing functions.

Dubem and Okwuashi [14] on his paper titled significant factors influencing decisions to outsource facilities management (FM) service in Nigeria's public hospitals. The purpose of this paper is to examine the theoretical trends in outsourcing of FM functions and the current state of FM practice using Nigeria and UK as case studies.

The research used a combination of literature review and questionnaire survey. The questionnaire was conducted to further explore (through cooperative analysis the perception of 30 (155 from UK and 15 from Nigeria) carefully selected facilities managers in UK and Nigeria who are subscribing members of British institute of facilities management (BIIFM) and international Facilities association (IFMA) Nigeria's chapter respectively; 22 respondents consisting of 13 received from UK respondents and from Nigeria responded to the survey giving a response rate among other things that FM has grown from the traditional day-to-day operational management to being a strategic management tool, while janitorial services and facilities maintenance remain the most outsourced FM services, the most outsourced FM services. Furthermore, the findings also revealed that 25 of the 31 factors were significant in explaining the decision to outsource FM service in Nigeria's public hospitals, while 15 of them grouped into six broad categories were selected based on their factor loading during further analysis. Besides, it was equally established that to improve performance standard, to improve quality of services and to improve timely delivery of services are the top three related factors.

\section{Theoretical Framework}

This study is based on Transaction Cost Economics (TCE) theory. This has been the most utilized theory of outsourcing. The main architect of the TCE theory is Oliver Williamson [18-20] who received a Nobel Memorial Prize in Economics Sciences in 2009. TCE is concerned with understanding economic exchange in situations of complex transactions. A source of complexity is the fact that transactions occur not in isolation, but also within a broader system of organizations and institutions. TCE tries to help us understand how individuals and groups make and should make decisions in a way that generates economically efficient outcomes. To achieve the goal calls for understanding complex contracting in its entirety [19] in which contracting parties have the foresight to create safeguards to maintain the integrity of the exchange relationships. TCE is perceived to provide the best decision making tools to help organizations to decide to outsource and to prepare themselves for forthcoming outsourcing arrangements. The governance features of the theory influenced that it has been applied in studying the managing relationship phase, whilst the concept of switching costs made the theory applicable in the reconsideration phase. Although it has been exercised extensively in outsourcing applications, the TCE has several indulgencies. It was found that original mapping to the TCE framework only explained few IT sourcing decisions and generated much more anomalies in their sample. Another critique could be that TCE relies on a single transaction as a unit of analysis, neglecting the cotemporary industrial collaborative arrangements. Finally, TCE is static, which doesn't correspond to dynamism of current business environment [15,21].

\section{Methodology}

The research design used in this study is the survey. It was considered appropriate because of its advantage in giving away unit equal opportunity of being selected. Also, it is reliable in giving accurate results. The study therefore has a descriptive survey design. Descriptive studies are mainly concerned with describing events as they occur in their natural setting without any manipulation of what is being observed. A total of 170 questionnaire were distributed to key personnel of 10 bakery industries in the study area. Out of this number, 150 questionnaire were returned, resulting in $88 \%$ return rate. The questionnaire was structured to address the objectives of the study. The researcher used five point likert scales which provide cogent results in similar studies.

\section{Data analysis}

Spearman's correlation was employed in analysis. The hypotheses were tested using the correlation coefficient, coefficient of determination and two tailed test distribution (t) statistical tool at a 5\% level of significance.

Decision rule: Accept $\mathrm{H}_{0}$ if the calculated value is less than the table value. Reject $\mathrm{H}_{0}$ if otherwise.

\section{Results and Discussions}

\section{Correlations}

A Pearson's correlation was run to determine the relationship between operational labor cost and outsourcing values. There was very weak positive correlation between both values $(r=0.008, N=150$, $\mathrm{P}>0.01$ ) (Tables 1-4). This implies that the operational labor cost has tendency to decrease slightly with outsourcing.

Also there was very weak positive correlation between outsourcing 
Citation: Oluchi EB, Nome U (2017) Impact of Outsourcing on Productivity in Bakery Industry, Abakaliki Metropolis. J Bus Fin Aff 6: 308. doi: 10.4172/2167-0234.1000308

Page 4 of 6

\begin{tabular}{|c|c|c|}
\hline Output Created & & 29-07-2017 16:53 \\
\hline \multicolumn{3}{|l|}{ Comments } \\
\hline \multirow[t]{5}{*}{ Input } & Active Dataset & DataSet0 \\
\hline & Filter & <none> \\
\hline & Weight & $<$ none $>$ \\
\hline & Split File & $<$ none $>$ \\
\hline & $\mathrm{N}$ of Rows in Working Data File & 224 \\
\hline \multirow[t]{2}{*}{ Missing Value Handling } & Definition of Missing & User-defined missing values are treated as missing. \\
\hline & Cases Used & Statistics are based on cases with no missing data for any variable used. \\
\hline \multirow[t]{5}{*}{ Syntax } & & CORRELATIONS \\
\hline & & NARIABLES=OUTS RB OLT OUS \\
\hline & & /PRINT=TWOTAIL NOSIG \\
\hline & & ISTATISTICS DESCRIPTIVES XPROD \\
\hline & & /MISSING=LISTWISE. \\
\hline \multirow[t]{2}{*}{ Resources } & Processor Time & 00:00.1 \\
\hline & Elapsed Time & $00: 00.0$ \\
\hline
\end{tabular}

Table 1: Correlations.

\begin{tabular}{|c|c|c|c|}
\hline & Mean & Std. Deviation \\
\hline Operational Labour Cost & 2.2067 & 0.79678 \\
\hline Reject Bread & 2.22 & 0.79318 \\
\hline Operational Labour Time & 2.2733 & 0.82655 \\
\hline Outsourcing & 2.2333 & 0.78078 \\
\hline
\end{tabular}

Table 2: Descriptive statistics.

\begin{tabular}{|c|c|c|c|c|c|}
\hline \multicolumn{6}{|c|}{ Correlations $^{b}$} \\
\hline & & Operational Labour Cost & Reject Bread & Operational Labour Time & Outsourcing \\
\hline \multirow{4}{*}{$\begin{array}{l}\text { Operational Labour } \\
\text { Cost }\end{array}$} & Pearson Correlation & 1 & -0.041 & -0.046 & 0.008 \\
\hline & Sig. (2-tailed) & & 0.622 & 0.58 & 0.92 \\
\hline & Sum of Squares and Cross-products & 94.593 & -3.82 & -4.473 & 0.767 \\
\hline & Covariance & 0.635 & -0.026 & -0.03 & 0.005 \\
\hline \multirow[t]{4}{*}{ Reject Bread } & Pearson Correlation & -0.041 & 1 & -0.123 & 0.133 \\
\hline & Sig. (2-tailed) & 0.622 & & 0.134 & 0.104 \\
\hline & Sum of Squares and Cross-products & -3.82 & 93.74 & -12.02 & 12.3 \\
\hline & Covariance & -0.026 & 0.629 & -0.081 & 0.083 \\
\hline \multirow{4}{*}{$\begin{array}{l}\text { Operational Labour } \\
\text { Time }\end{array}$} & Pearson Correlation & -0.046 & -0.123 & 1 & $-.245^{\star *}$ \\
\hline & Sig. (2-tailed) & 0.58 & 0.134 & & 0.003 \\
\hline & Sum of Squares and Cross-products & -4.473 & -12.02 & 101.793 & -23.567 \\
\hline & Covariance & -0.03 & -0.081 & 0.683 & -0.158 \\
\hline \multirow[t]{4}{*}{ Outsourcing } & Pearson Correlation & 0.008 & 0.133 & $-.245^{* *}$ & 1 \\
\hline & Sig. (2-tailed) & 0.92 & 0.104 & 0.003 & \\
\hline & Sum of Squares and Cross-products & 0.767 & 12.3 & -23.567 & 90.833 \\
\hline & Covariance & 0.005 & 0.083 & -0.158 & 0.61 \\
\hline
\end{tabular}

${ }^{* *}$ Correlation is significant at the 0.01 level (2-tailed).

bistwise $\mathrm{N}=150$

Table 3: A Pearson's correlation to determine the relationship between operational labor cost and outsourcing values.

and reject bread manufacture $(\mathrm{r}=0.133, \mathrm{~N}=150, \mathrm{p}>0.01)$. This implies that outsourcing does necessarily reduce the rate of reject bread manufacture.

Another Pearson's correlation was run to determine the relationship between operational labor time and outsourcing. There was negative correlation between both values $(\mathrm{r}=-0.245, \mathrm{~N}=150, \mathrm{P}<0.01)$. This result evidently shows that operational labor time has the tendency to decrease with outsourcing in the bread manufacturing industry.

\section{Conclusion and Recommendation}

Corporate rationality demands that management must maximise economic efficiency and corporate profitability. There is growing need for management to lower cost of production in order for efficiency to increase. This goal is what outsourcing tends to achieve. It therefore seeks to eliminate wastes such as labour hours of work, rejects and cost of production. With the increased global recession which affects Nigeria, the increase in cost of business tends to grow geometrically, especially in the bread industry.

Ugochukwu and Nwaoma [17] in a study of outsourcing policy in Nigeria public Universities: Issues and challenges, found that there was the problem of staff disengagement and inability of contractors to pay minimum wage. Babatunde [13] found that the more an organization 
Citation: Oluchi EB, Nome U (2017) Impact of Outsourcing on Productivity in Bakery Industry, Abakaliki Metropolis. J Bus Fin Aff 6: 308. doi: 10.4172/2167-0234.1000308

Page 5 of 6

\begin{tabular}{|c|c|c|c|c|c|c|c|}
\hline \multicolumn{8}{|c|}{ Correlations $^{b}$} \\
\hline & & & & $\begin{array}{c}\text { Operational Labour } \\
\text { Cost }\end{array}$ & Reject Bread & $\begin{array}{c}\text { Operational Labour } \\
\text { Time }\end{array}$ & Outsourcing \\
\hline \multirow{8}{*}{ operational Labour Cost } & \multicolumn{3}{|c|}{ Pearson Correlation } & 1 & -0.041 & -0.046 & 0.008 \\
\hline & \multicolumn{3}{|c|}{ Sig. (2-tailed) } & & 0.622 & 0.580 & 0.920 \\
\hline & \multicolumn{3}{|c|}{ Sum of Squares and Cross-products } & 94.593 & -3.820 & -4.473 & 0.767 \\
\hline & \multicolumn{3}{|c|}{ Covariance } & 0.635 & -0.026 & -0.030 & 0.005 \\
\hline & \multicolumn{3}{|c|}{ Bias } & 0 & 0.002 & 0.002 & 0.000 \\
\hline & \multirow{3}{*}{ Bootstrapalp } & \multicolumn{2}{|l|}{ Std. Error } & 0 & 0.080 & 0.079 & 0.083 \\
\hline & & \multirow{2}{*}{ 95\% Confidence Interval } & Lower & 1 & -0.191 & -0.188 & -0.155 \\
\hline & & & Upper & 1 & 0.118 & 0.109 & 0.174 \\
\hline \multirow{8}{*}{ Reject Bread } & \multicolumn{3}{|c|}{ Pearson Correlation } & -0.041 & 1 & -0.123 & 0.133 \\
\hline & \multicolumn{3}{|c|}{ Sig. (2-tailed) } & 0.622 & & 0.134 & 0.104 \\
\hline & \multicolumn{3}{|c|}{ Sum of Squares and Cross-products } & -3.820 & 93.740 & -12.020 & 12.300 \\
\hline & \multicolumn{3}{|c|}{ Covariance } & -0.026 & 0.629 & -0.081 & 0.083 \\
\hline & \multicolumn{3}{|c|}{ Bias } & 0.002 & 0 & 0.003 & 0.000 \\
\hline & \multirow{3}{*}{ Bootstrap alp } & \multicolumn{2}{|l|}{ Std. Error } & 0.080 & 0 & 0.082 & 0.079 \\
\hline & & 95\% Confidence Interval & Lower & -0.191 & 1 & -0.283 & -0.028 \\
\hline & & 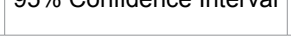 & Upper & 0.118 & 1 & 0.041 & 0.284 \\
\hline \multirow{8}{*}{ Operational Labour Time } & \multicolumn{3}{|c|}{ Pearson Correlation } & -0.046 & -0.123 & 1 & $-.245^{* *}$ \\
\hline & \multicolumn{3}{|c|}{ Sig. (2-tailed) } & 0.580 & 0.134 & & 0.003 \\
\hline & \multicolumn{3}{|c|}{ Sum of Squares and Cross-products } & -4.473 & -12.020 & 101.793 & -23.567 \\
\hline & \multicolumn{3}{|c|}{ Covariance } & -0.030 & -0.081 & 0.683 & -0.158 \\
\hline & \multirow{4}{*}{ Bootstrap alp } & \multicolumn{2}{|l|}{ Bias } & 0.002 & 0.003 & 0 & 0.002 \\
\hline & & \multicolumn{2}{|l|}{ Std. Error } & 0.079 & 0.082 & 0 & 0.077 \\
\hline & & \multirow{2}{*}{ 95\% Confidence Interval } & Lower & -0.188 & -0.283 & 1 & -0.386 \\
\hline & & & Upper & 0.109 & 0.041 & 1 & -0.095 \\
\hline \multirow{8}{*}{ Outsourcing } & & Pearson Correlation & & 0.008 & 0.133 & $-.245^{* *}$ & 1 \\
\hline & & Sig. (2-tailed) & & 0.920 & 0.104 & 0.003 & \\
\hline & Sum of & Squares and Cross-produc & & 0.767 & 12.300 & -23.567 & 90.833 \\
\hline & & Covariance & & 0.005 & 0.083 & -0.158 & 0.610 \\
\hline & & Bias & & 0.000 & 0.000 & 0.002 & 0 \\
\hline & Rentctranalp & Std. Error & & 0.083 & 0.079 & 0.077 & 0 \\
\hline & Doulstidp & 95\% Confidence Interval & Lower & -0.155 & -0.028 & -0.386 & 1 \\
\hline & & 95\% commence interval & Upper & 0.174 & 0.284 & -0.095 & 1 \\
\hline
\end{tabular}

${ }^{* *}$ Correlation is significant at the 0.01 level (2-tailed).

b\$bootstrap_split=0, Listwise $\mathrm{N}=150$.

alpUnless otherwise noted, bootstrap results are based on 1000 bootstrap samples.

Table 4: A Pearson's correlation was run to determine the relationship between operational labor time and outsourcing values.

outsourced, the high its organization growth and productivity and average production cost. The present study confirms that operational labour cost can slightly decrease with outsourcing decision in the present economic condition. This result suggests invariably that outsourcing might be intensified on grounds that it confers competitive advantage through the reduction and control of the operating costs during the current inflationary moment. Also, outsourcing has very weak relationship with rejects bread manufactured. This result tends to suggest that outsourcing does guarantee maximum elimination of bread rejects in the industry. Okogwu [11] argued that outsourced services are more efficient by experienced third party. Also, Dubem and Okwuashi [14] found that outsourcing involves use of high profile strategies which provide cost effective, high quality facilities. Therefore, although outsourcing may reduce operational labour time of manufacturing facility, the operating labour cost has the tendency to increase due to inflation. It is therefore evident that the high cost of bread in the market is as a result of high cost of production which outsourcing has not been able to reduce.

Managers in the industry: Eze argued that Nigeria needs a labour force that is cost effective and attractive to the global business.
Furthermore the results of this study tend to indicate that outsourcing represents an attempt at standardizing Nigeria's labour force and at the same time, enhancing the global competitiveness of its human capital [22-27]. Outsourcing therefore would practically help to drive down cost through the conscious engagement and use of people that constitute critical mass of those employed to enhance productivity. The management of the firms in the bread industry should engage in increased outsourcing to enhance productivity through cost reduction in the areas of reduced labour cost, wastage in rejects bread manufacture and save more operational time involved.

\section{References}

1. Mella P, Pellicelli M (2008) The Origin of Value Based Management: Five Interpretative Models of an unavoidable Evolution. International Journal of knowledge, Culture and Change Management 8: 23-32.

2. Mella P (2005) Performance Indicators in Business Value-Creating Organizations. Economic Aziendale online, pp: 25-52.

3. Van JAM (1999) Coordinating investment, Production and Subcontracting Management Sciences 45: 954-970.

4. Iyaniwura O, Osoba AM (1983) Measuring Productivity: Conceptual a Statistical problems: Improvement of statistics. In: Osoba AM editor. Productivity in Nigeria, Proceedings of a National conference NISER, Ibadan. 
Citation: Oluchi EB, Nome U (2017) Impact of Outsourcing on Productivity in Bakery Industry, Abakaliki Metropolis. J Bus Fin Aff 6: 308. doi: 10.4172/2167-0234.1000308

Page 6 of 6

5. Antle MJ, Capalbo SM (1988) An Introduction to Recent Development in production Theory and Productivity Measurement. In: Capalbo SM, Antle MJ editors. Agricultural productivity: Measurement and Explanation. Resources for the future, Inc, Washington, D.C.

6. Taylor F (1911) Principles of Scientific Management. N.Y: Harpers and Brothers, New York.

7. Prokopenko J (1987) Productivity Measurement: A practical Handbook. International Labor Organization, Geneva.

8. Olayide SO, Heady EO (1982) Introduction to Agricultural Production Economics. Ibadan University Press, Nigeria.

9. Wonnacoh P and Wonnacott R (1986) Economics. (3 ${ }^{\text {rd }}$ edn.), McGraw-Hill Book Company, New York.

10. Liu C (2006) Productivity Changes of Credit Department of farmers' Association of the MAN-TOU County in Taiwan 1995-2004.

11. Okogwu F (2013) Out Sourcing of library services in Nigerian University Libraries: The Pros and Cons. Brazilian Journal of Information Science 7: 20-28.

12. Bryson J (1999) Effective Library and Information Centre Management. (2 edn.), Gower Publisher, USA

13. Babatunde A (2013) Out Sourcing as a Strategic Tool for Organizational Performance: An Exploratory Study of Nigerian Food, Beverage and Tobacco Industry. Journal of Management Policies and Practices 1: 1-20.

14. Dubem I, Okwuashi O (2016) Significant factors influencing outsourcing decision for facilities management (FM) services: A study on Nigeria's public hospitals. Property Management 33: 59-82.

15. Zoran P, Jorgen LP (2007) Outsourcing Process and Theories. POMS 18th Annual Conference, Dallas, Texas, U.S.A.
16. Momme J (2001) Outstanding Manufacturing to Suppliers. Aalborg University, Denmark.

17. Ugochukwu UI, Nwaoma PC (2015) Outsourcing Policy in the Nigerian Public Universities: Issues and Challenges. International Journal of Economic and Business Review 3: 167-172.

18. Williams OE (1975) Markets and hierarchies: Analysis and antitrust implications: A Study in the Economics of Internal Organization. Free Press, New York.

19. Williams OE (1985) The Economic Institutions of capitalism: Firms, Markets Relational Contracting. Free Press, New York.

20. Williams OE (1996b) The Mechanisms of Governance. Oxford University Press, New York.

21. Lacity MC, Willocks LP (1995) Interpreting Information Technology Sourcing Decisions from a Transaction Cost Perspective: Findings and Critique. Accounting Management and Information Technology 5314: 204-244.

22. Click RL, Duening TN (2005) Business Process Outsourcing: The Competitive Advantage. John Wiley \& Sons, Hoboken.

23. Corbett MF (2004) The Outsourcing Revolution: Why it makes sense and how to do it right. Dearborn Trade Publishing, Chicago Department of Production Aalbrog University, Aalborg.

24. Franceschini F, Galetto M, Pignatelli A, Varetto M (2003) Outsourcing: Guidelines for a structured approach. International Journal of Benchmarking 10: 246-260.

25. Greaver MF (1999) Strategic Outsourcing: A Structured Approach to Outsourcing Decisions and Initiatives. AMACOM, New York.

26. Mclvor R (2005) The Outsourcing Process. Cambridge.

27. Stein P (1983) Human Resource Planning. McGraw, New York. 